\title{
Engineering Performance of Fly Ash Stabilized Çatalağzı clay
}

\author{
Emrah Dağli ${ }^{*}$, Ömer Faruk Çapar ${ }^{2}$ \\ 1* Zonguldak Bulent Ecevit University, Faculty of Engineering, Departmant of Civil Engineering, Zonguldak, Turkey, (ORCID: 0000-0002-5744-8151), \\ emrahdagli@beun.edu.tr \\ 2 Adana Alparslan Türkeş Bilim ve Teknoloji University, Faculty of Engineering, Departmant of Civil Engineering, Adana, Turkey, (ORCID: 0000-0002-6325-8223), \\ ofcapar@atu.edu.tr
}

(2nd International Conference on Applied Engineering and Natural Sciences ICAENS 2022, March 10-13, 2022)

(DOI: $10.31590 /$ ejosat.1081214)

\begin{abstract}
ATIF/REFERENCE: Dağlı E.\& Çapar, Ö. F. (2022). Engineering Performance of Fly Ash Stabilized Çatalağzı Clay. European Journal
\end{abstract} of Science and Technology, (34), 267-272.

\begin{abstract}
Stabilizing of soils can be done with physical, chemical and hydraulic methods. Chemical stabilization is one of the most widely used method among them. In this study, low plasticity Çatalağzı clayey soil is chosen as a research material. F type of fly ash are used as a chemical additive. Soil is mixed with various amount $(0 \%, 10 \%, 20 \%$ and $30 \%)$ of fly ash. Index tests (hydrometer, specific gravity, liquid limit, plastic limit and standard compaction) were performed on clayey soil. Then samples prepared with optimum water content obtained from standard compaction test were exposed to unconfined compressive strength (UCS), moisture condition value (MCV) and California bearing ratio (CBR) tests. Curing time are selected as 0,7 and 28 days for UCS test. Curing for CBR test includes 28 days air curing and 4 days full soaking. MCV has no curing time. Addition of fly ash increase the UCS of untreated soil. UCS of samples for S10FA, S20FA and S30FA having 7 day of curing time is 1.46, 1.51 and 1.53 times of the Çatalağzı clay of having no curing time. Rate of increase in UCS gets slow down after 7 days. MCV of S10FA is 18.3 while it is 12.2 for Çatalağz1 clay which means $50 \%$ increase. Fly ash content after $10 \%$ have no significant change and even decrease slightly. CBR values are increased with an addition of fly ash also. It has been concluded that this type of fly ash increases the engineering performance of untreated clay but it is not suitable to be a subgrade for highway when taking into account of CBR value
\end{abstract}

Keywords: Clayey soil, California bearing ratio, Fly ash, Moisture condition value, Unconfined compressive strength

\section{Uçucu Külle Stabilize Edilen Çatalağzı Kili Mühendislik Performansı}

$\ddot{O} \mathbf{z}$

Zeminlerin stabilizasyonu fiziksel, kimyasal ve hidrolik yöntemler ile yapılabilmektedir. Kimyasal stabilizasyon, bu yöntemlerin arasından en yaygın kullanılanıdır. Bu çalışmada, düşük plastisiteli Çatalağzı kil numunesi araştırma malzemesi olarak seçilmiştir. F tipi uçucu kül kimyasal katkı olarak kullanılmıştır. Zemin çeşitli oranlarda (0\%, 10\%, 20\% ve 30\%) uçucu kül ile karıştırılmıştır. Killi zemin üzerinde indeks deneyleri (hidroemetre, özgül ağırlık, likit limit, plastik limit ve standart kompaksiyon) gerçekleştirilmiştir. Sonra, standart kompaksiyon deneyinden elde edilen optimum su içeriğinde hazırlanan numuneler, serbest basınç (UCS), nemlilik şartları (MCV) ve Kaliforniya taşıma oranı (CBR) deneyine maruz kalmıştır. Kür süresi UCS deneyi için 0 , 7 ve 28 gün olarak seçilmiştir. CBR deneyindeki kür 28 gün havada kürlerme ve 4 gün tam suda beklemeyi içermektedir. MCV için kür süresi yoktur. Uçucu kül ilavesi zeminin UCS değerini artırmaktadır. S10FA, S20FA ve S30FA numunelerine ait 7 gün kürlü durumdaki UCS değerleri, kür süresiz Çatalağız kilinin 1.46, 1.51 ve 1.53 katıdır. UCS artış hızı 7 günden sonra yavaşlamaktadır. S10FA için MCV 18.3 iken Çatalağzı kili için 12.2 olmuştur bu da yaklaşık 50\% artış anlamına gelmektedir. Uçucu kül katkı oranı 10\%'den sonra önemli bir değişim olmamış hatta biraz azalmıştır. CBR değerleri de uçucu kül ilavesi ile artmıştır. Uçucu külün, kilin mühendislik performansının artırdığı fakat CBR değeri düşünüldüğünde yol alt dolgusu olmak için yeterli olmadığı sonucuna varılmıştır.

Anahtar Kelimeler: Killi zemin, Kaliforniya taşıma oranı, Uçucu kül, Nemlilik şartları, Serbest basınç

* Corresponding Author: emrahdagli@beun.edu.tr 


\section{Introduction}

Fly ash is a waste product generated in coal/lignite based thermal power plants. They are formed as a result of the transport of coal, which is burned by grinding very finely in thermal power plants, with flue gases. Since they will adversely affect the environment, fly ash is prevented from leaving the power plant chimney and mixing into the air. For this purpose, ashes are collected by mechanical and electrostatic methods and stored around the power plant or in other suitable places. Amount of fly ash produced is 600 million tons per annum in the world [1]. Fly ash has numerous applications in construction, ceramic industries, soil stabilization for highway construction [2-8]. In fact, fly ash can be even used as a potential raw material for the synthesis of nano porous materials such as zeolites or mesoporous silica due to its high silica content [9]. Although the global use of coal to prevent global warming decreased by $4.4 \%$ in 2021 , the global market value of fly ash is 3,757.911 million dollars. Million tons of fly ash, which is still stored in the form of waste produced by thermal power plants, is stored for future use.

In this study, low plasticity Çatalağzı clay and F type of fly ash was used as a research material. Index parameters of soil were obtained from physical identity tests (specific gravity, hydrometer, liquid limit, plastic limit and standard compaction). Specimens for strength tests were prepared with an optimum water content of soil obtained from standard compaction test. Unconfined Compressive Strength (UCS) tests were carried out for all mixtures and curing time was used as 0, 7 and 28 days. Moisture Content Value (MCV) tests were conducted without curing. California Bearing Ratio (CBR) test was also performed for specimens by 28 days air curing +4 days full soaking. The aim of this study is to evaluate the impact of $F$ type fly ash on clayey soil's engineering properties.

\section{Material and Method}

\subsection{Materials}

Çatalağzı clayey were used in this study. This soil was obtained from Kilimli district of Zonguldak. Index parameters of the soil is presented in the Table 1.

Table 1. Index parameters of clay

\begin{tabular}{|c|c|}
\hline Material & Soil \\
\hline Soil Type & CL \\
\hline Clay (\%) & 55 \\
\hline Silt (\%) & 45 \\
\hline LL & 36 \\
\hline PL & 19 \\
\hline PI & 17 \\
\hline $\mathrm{G}_{\mathrm{s}}$ & 2.63 \\
\hline$\rho_{\mathrm{d}(\max )}$ & $1.70 \mathrm{~g} / \mathrm{cm}^{3}$ \\
\hline $\mathrm{W}_{\text {opt }}(\%)$ & 16.97 \\
\hline
\end{tabular}

Grain size distribution of the soil is obtained with a hydrometer test, details of it is given in ASTM D7928-17, 2017 [10] standard, in order to find out silt and clay percentages of soil. Clay and silt percentages of the clay is $55 \%$ and $45 \%$ respectively.

This soil is classified as CL (low plasticity clay) according to plasticity chart identified in ASTM D2487-17 ${ }^{\varepsilon 1}$ [11] standard. Maximum dry density and optimum water content is $1.70 \mathrm{~g} / \mathrm{cm}^{3}$ and $16.97 \%$ respectively as a result of standard compaction test conforming to ASTM D698-12 $2^{\varepsilon 2}$ (2012) standard [12].

Fly ash was taken from Eren Enerji Thermal Power Plant. Chemical composition of fly ash used in this study was determined with XRF analysis. Results are given in Table 2.

Table 2. Chemical composition of fly ash

\begin{tabular}{|c|c|}
\hline Component & $\begin{array}{c}\text { Concentration } \\
(\%)\end{array}$ \\
\hline $\mathrm{SiO}_{2}$ & 48.20 \\
\hline $\mathrm{Al}_{2} \mathrm{O}_{3}$ & 21.08 \\
\hline $\mathrm{Fe}_{2} \mathrm{O}_{3}$ & 18.32 \\
\hline $\mathrm{K}_{2} \mathrm{O}$ & 3.88 \\
\hline $\mathrm{CaO}$ & 2.49 \\
\hline $\mathrm{TiO}_{2}$ & 2.35 \\
\hline $\mathrm{MgO}_{\mathrm{SO}}$ & 1.89 \\
\hline $\mathrm{SO}_{3}$ & 0.98 \\
\hline $\mathrm{Na}_{2} \mathrm{O}$ & 0.57 \\
\hline
\end{tabular}

This fly ash is classified as F type according to ASTM C618 (2019) standard [13] since it meets both criteria of having $\mathrm{CaO}<$ $18 \%$ and $\mathrm{SiO} 2+\mathrm{Al} 2 \mathrm{O} 3+\mathrm{Fe} 2 \mathrm{O} 3>70 \%$.

\subsection{Method}

In this study, varying fly ash additive $(0 \%, 10 \%, 20 \%$ and $30 \%)$ and curing time (0, 7 and 28 days) were used to evaluate the UCS performance of untreated and treated Çatalağzı soil. CBR tests were carried out for all mixtures cured for 28 days following 4 days full soaking $(28+4 i)$. MCV tests were also carried out. Detailed experiment program and codes for mixtures are given in Table 3 .

Table 3. Experiment Program and Mixture Codes

\begin{tabular}{|c|c|c|}
\hline Material & Code & Test \\
\hline Çatalağzı Soil & S & $\begin{array}{l}\text { UCS (0, 7, 28 days) } \\
\text { MCV, CBR (28+4i) }\end{array}$ \\
\hline Fly Ash & FA & $\ldots$ \\
\hline Soil + 10\% FA & S10FA & $\begin{array}{l}\text { UCS (0, 7, 28 days) } \\
\text { MCV, CBR (28+4i) }\end{array}$ \\
\hline Soil + 20\% FA & S20FA & $\begin{array}{l}\text { UCS (0, 7, 28 days) } \\
\text { MCV, CBR (28+4i) }\end{array}$ \\
\hline Soil + 30\% FA & S30FA & $\begin{array}{c}\text { UCS (0, 7, 28 days) } \\
\text { MCV, CBR (28+4i) }\end{array}$ \\
\hline
\end{tabular}

\subsubsection{Unconfined Compressive Strength Test}

This test was carried out according to ASTM D2166/D2166M-16 standard [14]. Samples of unconfined compressive strength (UCS) tests were prepared with Harvard mini compactor equipment having a $33 \mathrm{~mm}$ diameter and $71 \mathrm{~mm}$ height. All samples exposed to UCS tests were compacted in a 5 layer with 10 blows to give same energy with standard compaction test. Three identical samples (having same curing time and additive ratio) were used. Samples having 7 and 28 days of curing were stored at desiccators. After that, samples ready for tests were placed on the test device. Semi-automatic GDS test device was used to get data. Rate of loading was approximately $0.71 \mathrm{~mm} / \mathrm{min}$ which is equal to $10 \%$ displacement in 10 minutes. Axial stress-axial strain graphs were plotted. Maximum stress determined from that graph is defined as the unconfined compressive strength. 


\subsubsection{Moisture Condition Value Test}

The test was performed with regarding to BS EN 13286-46 (2003) standard [15]. Moisture condition value (MCV) test was developed by British Highways. Aim of this test is to check the suitability of embankments in highways. It is not a timeconsuming test that it is the main advantage. This test ensures the evaluation of compactive effort in terms of blow numbers (B). In this test, approximately $1.5 \mathrm{~kg}$ soil specimen were mixed thoroughly with optimum water. Hammer of $97 \mathrm{~mm}$ diameter and $7 \mathrm{~kg}$ weight were dropped from $25 \mathrm{~cm}$ vertical distance on the compacted specimen. Blow numbers were used as 1, 2, 4, 8, 16, 32, 64, 128 and 256. Penetration numbers (n) were recorded after per blows. Steepest straight line is drawn and extended till it intercepts $5 \mathrm{~mm}$ of penetration difference. $\mathrm{X}$ axis of interception point gives the "B" value that is used for MCV calculation. Moisture condition value (MCV) is equal to 10 times logarithm of $\mathrm{B}(\mathrm{MCV}=10 \log \mathrm{B})$. Fig. 1 is the number of blows-penetration difference curve of Çatalağzı clay which is a typical example of soil.

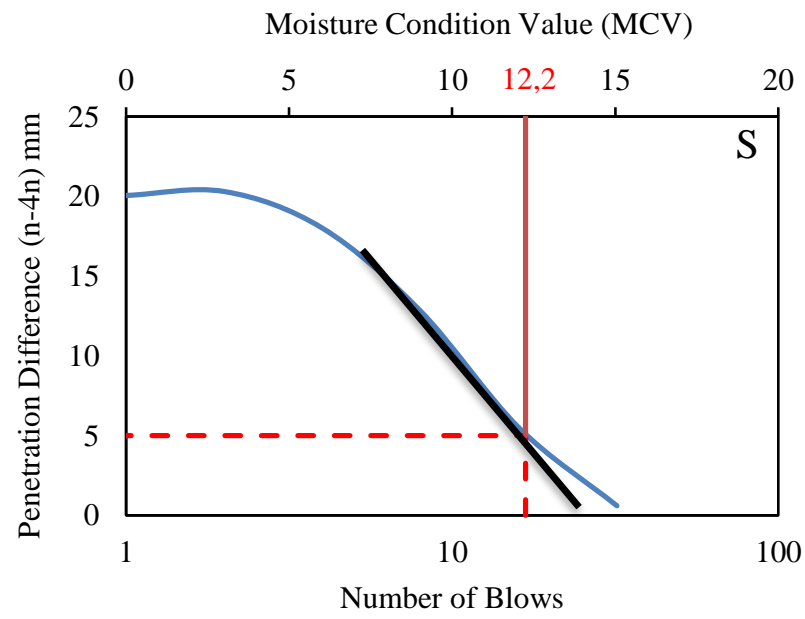

Fig. 1 Penetration difference-blow curve for soil

\subsubsection{California Bearing Ratio Test}

California bearing ratio (CBR) tests were performed according to BS EN 13286-47 (2012) standard [16]. Samples were prepared with an optimum water content of soil. Compaction were performed with an automatic compactor equipment by applying 61 blows per 3 layers. Samples tested are all exposed to 28 days of air curing time following 4 days of full soaking. Loadpenetration data were recorded to find the CBR value

\section{Results and Discussion}

\subsection{Results}

Axial stress versus axial strain curves obtained from UCS tests are shown in Fig. 2, 3 and 4. Numbers written in the figure indicates the ith of 3 identical sample.
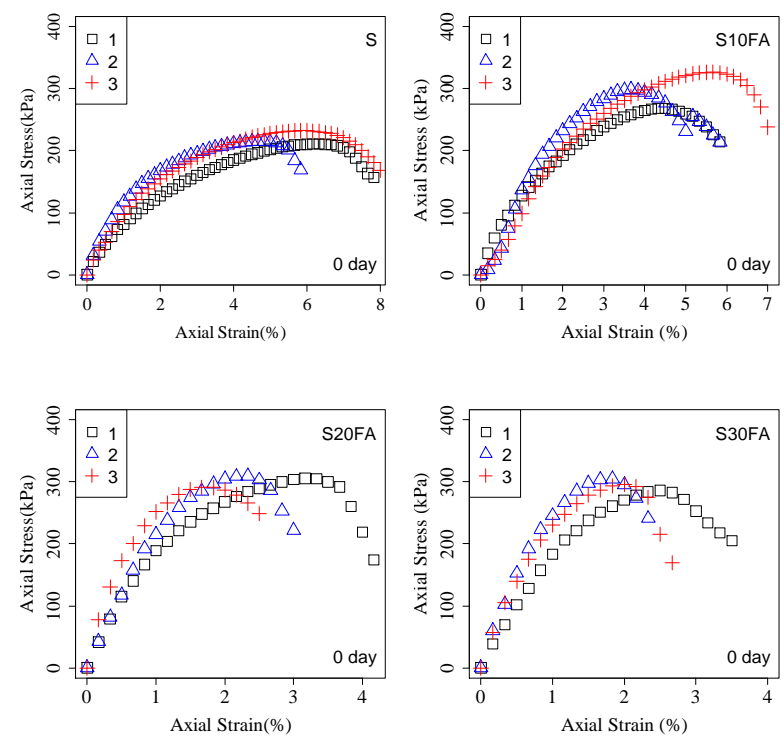

Fig. 2 Stress-strain curves of all mixtures for no curing

Fig 2 indicates that, axial strain value of maximum stress for untreated soil is approximately between 5\% and 6\%. Fly ash addition has a decreasing effect of Axial Strain Occurring at Maximum Stress (ASOAMS) as clearly seen. ASOAMS decreases $3.5 \%$ for $\mathrm{S} 10 \mathrm{FA}$ and minimum value of it is $1.5 \%$ for S30FA.
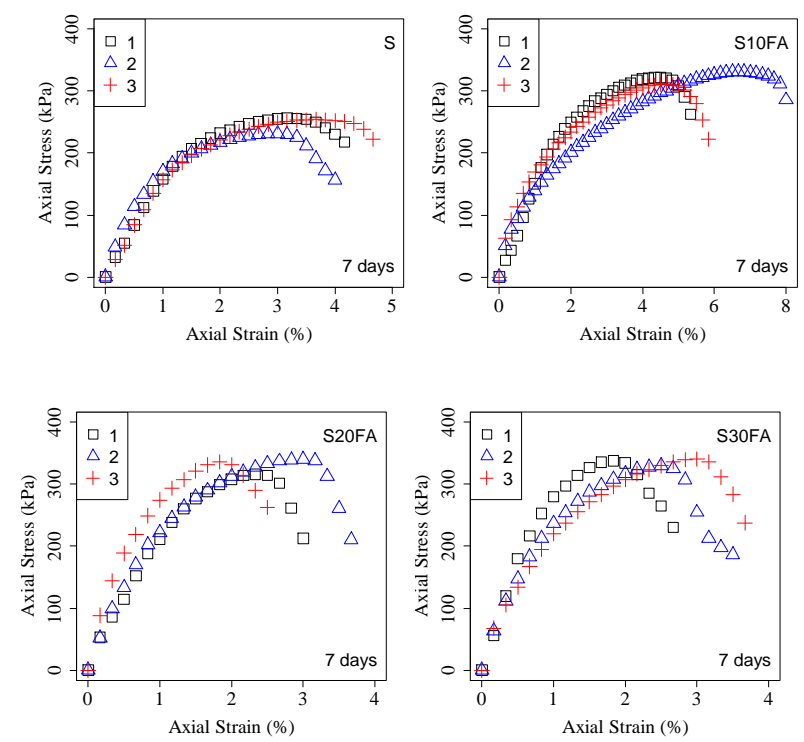

Fig. 3 Stress-strain curves of all mixtures for 7 days curing

Similar stress- strain behaviour is shown in Fig 3. Distinct difference is observed for untreated clay that ASOAMS reduces to $3 \%$ which can be attributed to curing time and reactions occurred. S10FA, S20FA and S30FA mixtures tend to behave similar for 7 days curing and ASOAMS is between $2 \%$ and $3 \%$. 

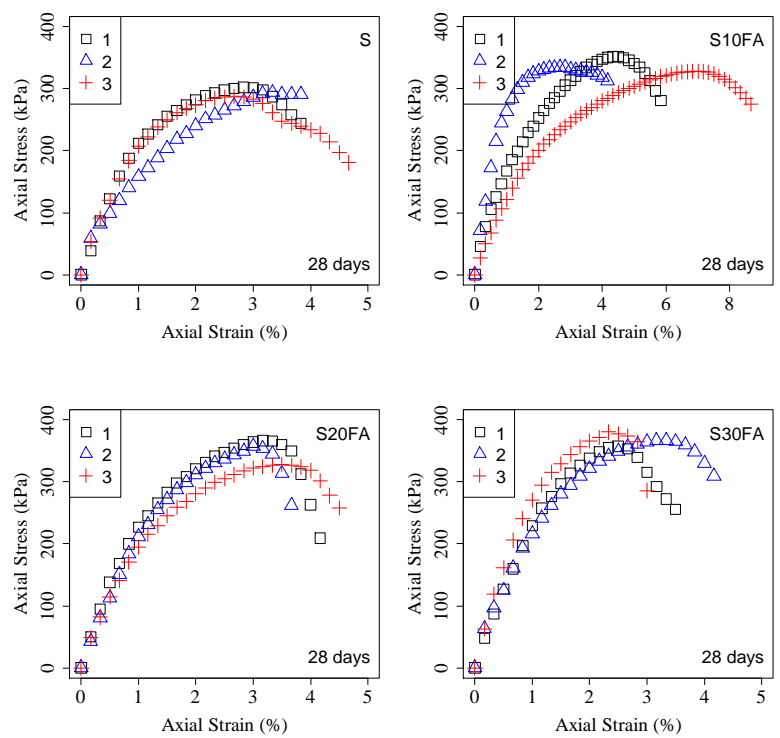

Fig. 4 Stress-strain curves of all mixtures for 28 days curing

Stress-strain behaviour of mixtures cured for 28 days are almost same with same curves of Fig 2. Main reasons for that is $\mathrm{F}$ type of fly ash having low cementing agent (especially $\mathrm{CaO}$ ) did not change the failure behaviour from ductile to brittle for S10FA, S20FA and S30FA. Furthermore, hydration and cementing reactions are still in progress after 28 days

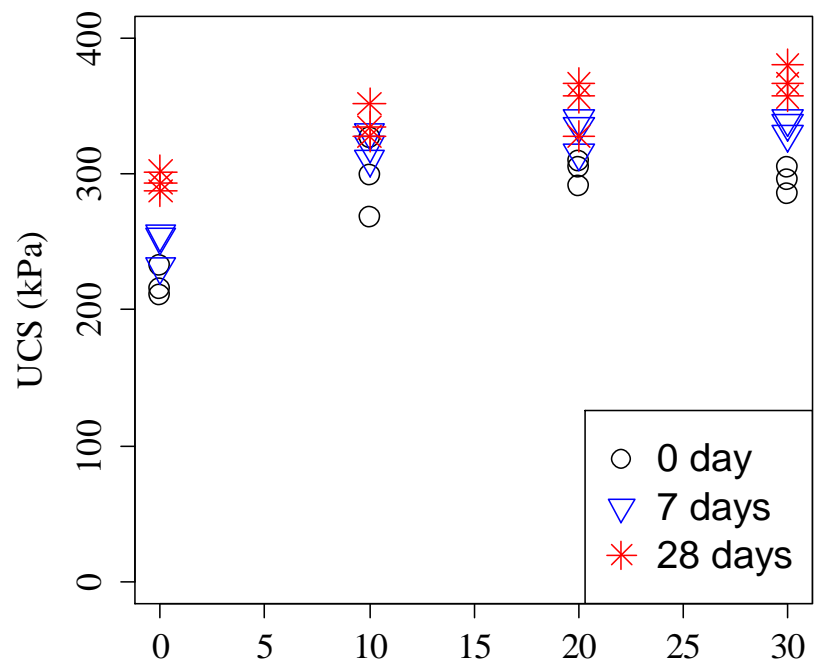

Fly Ash (\%)

Fig. 5 Effect of fly ash and curing time on UCS of soil

Results of various fly ash additive and curing time of unconfined compressive strength tests are presented in Figure 5. This figure shows that fly ash tends to increase slightly the UCS of Çatalağzı clay. UCS of S10FA, S20FA and S30FA for 7-day of curing are $1.46,1.51$ and 1.53 times of untreated clay of 0 day curing respectively. These values of S10FA, S20FA and S30FA reaches $1.54,1.60$ and 1.68 times for 28-day of curing.

UCS results of the test indicate that increasing fly ash content to $10 \%$ and $20 \%$ enhance UCS value apparently. However, after $20 \%$ fly ash, UCS value seems nearly same even a little increase. Increasing rate of UCS after 7 days is distinctly slower than first 7 days. Similar results are also obtained from the literature $[3,5,7,18]$. Since fly ash used in this study is F type, its hydratation and cementation reactions are not as effective as $\mathrm{C}$ type fly ash. This make no distinct change in UCS after 7 days curing.
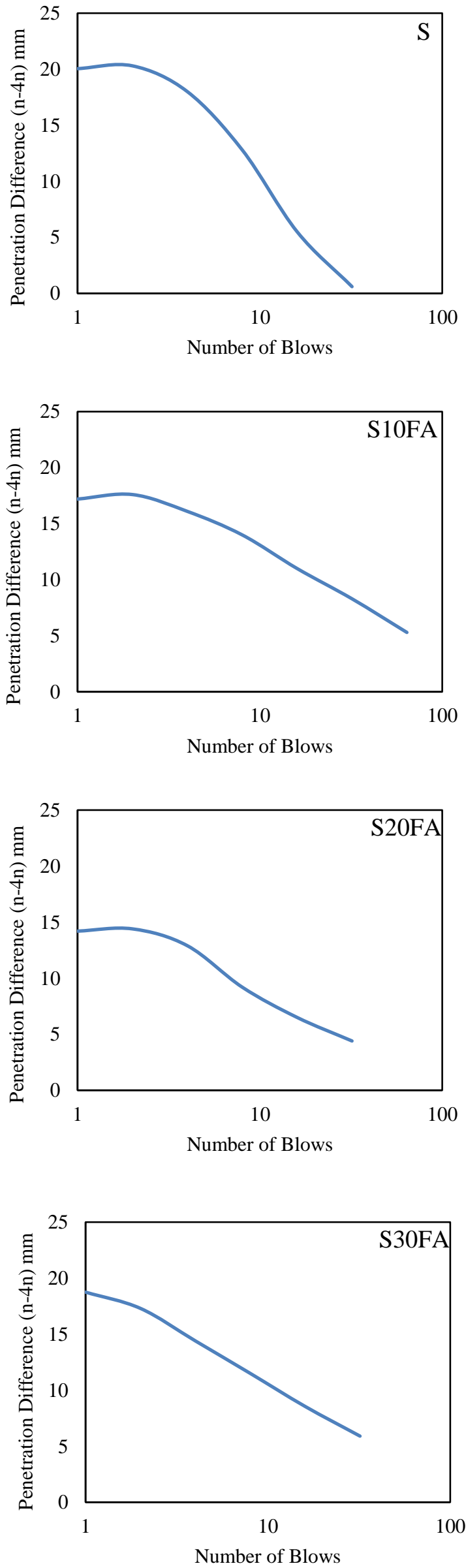

Fig. 6 Penetration-blow curves of MCV for all mixtures 
Fig 6, shows the penetration difference-number of blows graphs of all mixtures (S, S10FA, S20FA and S30FA). Increase in the blow number enhance slightly (nearly same) the penetration difference and sharp decrease is occurred after 4 blows. Different behaviour of fly ash stabilized mixtures and untreated clay are seen especially for the first 4 blows. Penetration differencenumber of blows graph of S30FA mixture is decreasing monotonic while others have no behaviour like that.

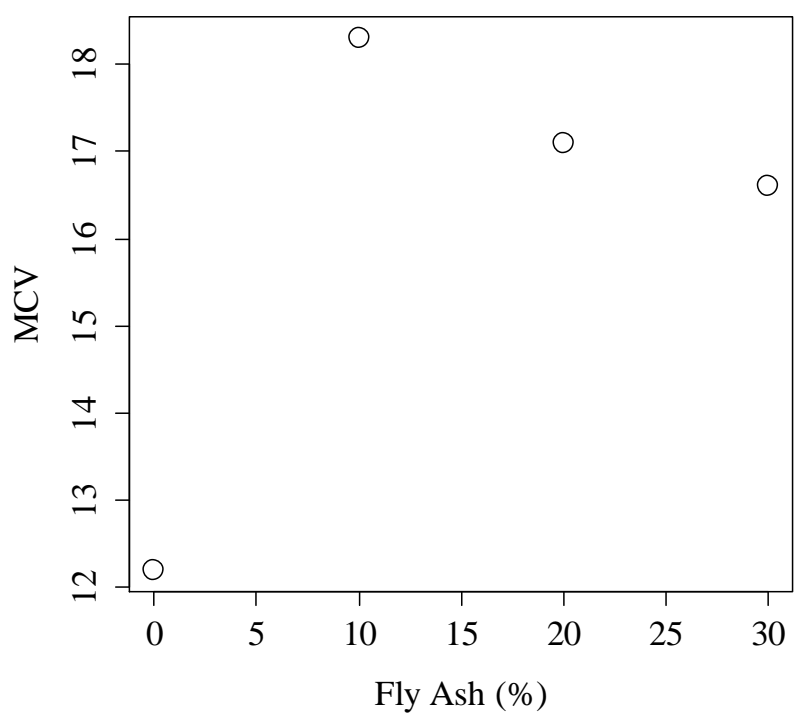

Fig. 7 Effect of fly ash on MCV of soil

Fly ash effect on MCV of soil is shown in Figure 7. Increasing fly ash additive from 0 to $10 \%$ increase the $\mathrm{MCV}$ of soil approximately $50 \%$ and it is the top value. MCV of S20FA and S30FA mixtures are 17.1 and 16.6 respectively which is lower than S10FA

MCV results of all mixtures including clay is higher than the lower limit of MCV value of 8.5 accepted [19]. MCV test contains no curing time and thus make the results of S10FA, S20FA and S30FA mixtures close to each other. By comparing MCV values with an exception of clay, minimum MCV of treated mixtures of S30FA is 0.91 times of S10FA.

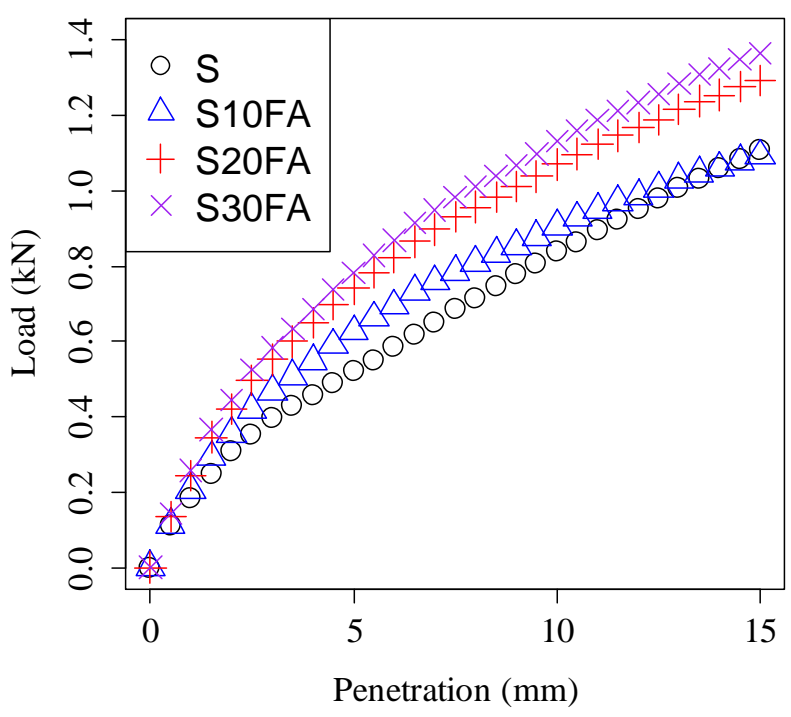

Fig. 8 Penetration-load curves of CBR for all mixtures

Load-penetration curves of all mixtures seems to be typical as shown in Figure 8. Approximate CBR values of all mixtures can be clearly understood that they are very close to each other.
For the first $2.5 \mathrm{~mm}$ penetration, load increase for all samples are fast compared to other $12.5 \mathrm{~mm}$ penetration. Curves of S20FA and S30FA mixtures separate from $\mathrm{S}$ and S10FA after $3 \mathrm{~mm}$ penetration. However, CBR values of them is not far away even it seems that some increase occurs when observed for Figure 9.

CBR values are increased with an increase in fly ash content as seen in Fig 9. CBR of untreated clay is $2.66 \%$. Fly ash addition of $10 \%$ enhance the CBR value to $3.18 \%$. After $20 \%$ fly ash addition, there is no significant change in CBR. Maximum CBR value is obtained for S30FA mixtures and it is $3.97 \%$. This increase has no sense even it seems $50 \%$ from untreated clay to S30FA. According to Turkish Highway Technical Specification (KGM, 2013) [17], soil has minimum of $15 \%$ of CBR value to be used as a subgrade in highways. There is no mixture of this study that satisfying this condition.

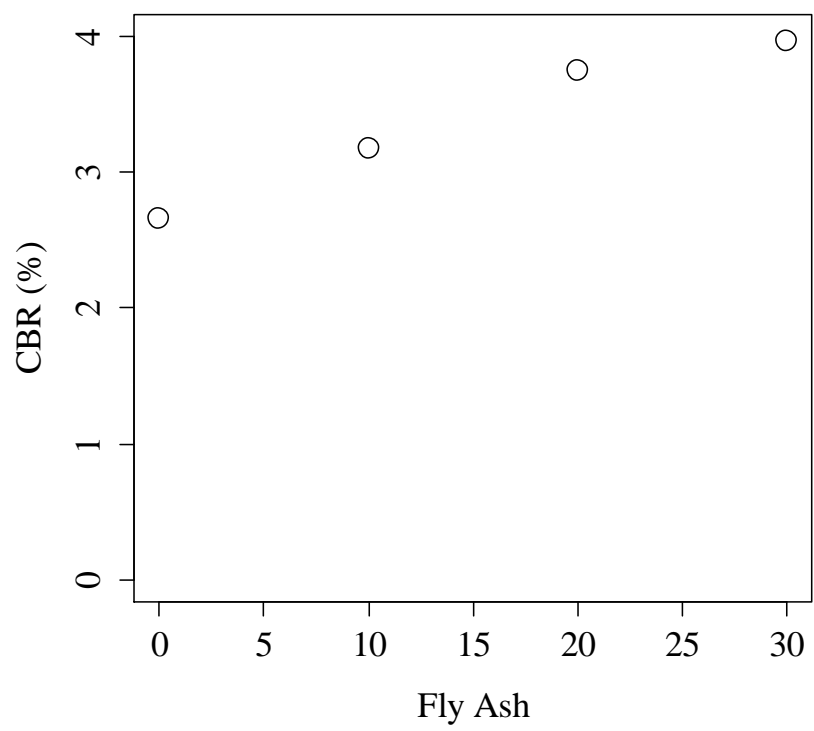

Fig. 9 Effect of fly ash on CBR of soil

CBR results of all mixtures are close to values of published literature. Pandian et al. (2001) [2] evaluated the maximum CBR value of 4.85 value for the mixture containing $20 \%$ fly ash. Brooks et al. (2011) [4] also found CBR value of 4.00 for $25 \%$ and 2.50 for untreated soil. Similar results are obtained by other studies $[8,20]$.

\section{Conclusions and Recommendations}

This study is performed to investigate the effect of fly ash additive on engineering properties of clay soil. F type of fly ash was used. UCS tests were conducted for the various curing time $(0,7$ and 28 day) and fly ash additive ratios $(0 \%, 10 \%, 20 \%$ and $30 \%)$. MCV tests were also performed for same fly ash additive ratios but with no curing time. CBR tests were carried out for all mixtures for curing time defined above. The conclusions written below are obtained.

1) Çatalağzı clay is a typical low plasticity clayey soil and engineering properties of it are in line of expectations.

2) Addition on fly ash increased the UCS of clay soil. However, after $20 \%$, fly ash has no prominent effect on UCS.

3) Increasing curing time enhanced the UCS of all mixtures including clay. On the other hand, UCS of the samples having 7 and 28 days curing are close to each other since the usage of low cementing fly ash. 
4) MCV results of fly ash stabilized mixtures are not far away from each other. One of the reasons of that there is no curing time. MCV of S10FA, S20FA and S30FA mixtures are higher than untreated clay.

5) CBR results indicates that, fly ash addition on clay increases $\mathrm{CBR}$ value but it is not acceptable to be a highway subgrade material. Low $\mathrm{CaO}$ fly ash (F type) has no sufficient effect to increase the CBR value at least $15 \%$.

\section{References}

[1] Türker, P., Erdoğan, B, Katnaş, F., \& Yeğinobalı, A. (2009). Classification and properties of fly ash in turkey" Turkish Cement Manufacturers Association, Tech. Rep. TÇMB /ARGE / Y03.03. (in Turkish).

[2] Pandian, N. S., Krishna, K. C., \& Sridharan A. (2001). California bearing ratio of soil/fly ash mixtures. Journal of Testing and Evaluation, 29(2), 220-226.

[3] Altun S., Sezer, A., \& Erol A. (2009). The effect of additives on the mechanical behavior of a silty soil. Cold Regions Science and Technology, 56, 135-140.

[4] Brooks, R., Udeyo, F. F., \& Takkalapelvi, K. V. (2011). Geotechnical properties of problem soils stabilized with fly ash. Journal of Materials in Civil Engineering, 23(5), 711716.

[5] Mccarthy, M. J., Csetenyi, L. J., Sachdeva, A., \& Dir, R. K. (2014). Engineering and durability properties of fly ash. Engineering Geology, 174, 139-148.

[6] Yao, Z. T., Ji, X. S., Sarker, P. K., Tang, J. H., Ge, L. Q., Xia, M. S., \& Xi, Y. Q. (2015). A comprehensive review on the applications of coal fly ash. Earth-Science Reviews, 141, 105-121.

[7] Dayığlu, M., Çetin, B., \& Nam, S. (2017). Stabilization of expansive belle fourche shale clay with different chemical. Applied Clay Science, 146, 56-69.

[8] Priyadarshee, A., Kumar, A., Gupta, D., \& Pushkarna, P. (2018). Compaction and strength behavior of tire crumblesfly ashed mixed with clay. Journal of Materials in Civil Engineering, 30(4), 1-9.

[9] Miricioiu, M. G., \& Niculescu V. C. (2020). Fly ash, from recycling to potential raw material for mesporous silica synthesis. Nano Materials, 10(3), 474.

[10] ASTM D7928-17 (2017), Standard test method for particlesize distribution (gradation) of fine-grained soils using the sedimentation (hydrometer analysis) ${ }^{1}$, ASTM Standard.

[11] ASTM D2487-17 ${ }^{\varepsilon 1}$ (2017). Standard practice for classification of soils for engineering purpose (unified soil classification system $)^{1}$, ASTM Standard.

[12] ASTM D698-12 $2^{\varepsilon 2}$ (2012). Standard test methods for laboratory compaction characteristics of soil using standard effort $\left(12400 \mathrm{ft}-\mathrm{lbf} / \mathrm{ft}^{3}\left(600 \mathrm{kN}-\mathrm{m} / \mathrm{m}^{3}\right)\right)^{1}$, ASTM Standard.

[13] ASTM C618 (2019). Standard specification for coal fly ash and raw or calcined natural pozzolan for use in concrete $^{1}$, ASTM Standard.

[14] ASTM D2166/D2166M-16 (2016). Standard test method for unconfined compressive strength of cohesive soil, ASTM Standard.

[15] BS EN 13286-46 (2003). Unbound and hydraulically bound mixtures part 46: test method for the determination of the moisture condition value, BSI Standard Publications, British Standard.

[16] BS EN 13286-47 (2012). Unbound and hydraulically bound mixtures part 47: test method for the determination of california bearing ratio, immediate bearing index, and linear swelling, BSI Standard Publications, British Standard.

[17] KGM (2013). Highway technical specification (infrastructures, engineering structures, bridges and tunnels, pavement and miscellaneous constructions), General Directorate of Highways.

[18] Mahedi, M., Çetin, B., \& White D. J. (2020). Cement, lime and fly ashes in stabilizing expansive soils: Performance evaluation and comparison. Journal of Materials in Civil Engineering, 32(7). 04020177.

[19] Matheson, G. D., \& Winter, M. G. (1997). Use and application of the mca with particular reference to glacial tills, Transport Research Laboratory, TRL Rep. 273.

[20] Sharma, N. K., Swain, S. K., \& Sahoo U. C. (2012). Stabilization of a clayey soil with fly ash and lime: A micro level investigation" Geotechnical and Geological Engineering, 30, 1197-1205. 